\title{
Problémy srovnávací pedagogiky jako předmětu vysokoškolské výuky ve světě a v českém prostředí
}

\author{
Eliška Walterová \\ Univerzita Karlova v Praze, Pedagogická fakulta, Ústav výzkumu a rozvoje vzdělávání
}

Redakci zasláno 1. 8. 2014 / upravená verze obdržena 10. 10. 2014 /

k uveřejnění přijato 13. 10. 2014

\begin{abstract}
Abstrakt: Studie se zabývá srovnávací pedagogikou jako předmětem vysokoškolské výuky. Záměrem je otevřít otázky, které dosud nebyly v českém prostředí diskutovány. Hlavním cílem je zmapovat současný stav a identifikovat problémy výuky srovnávací pedagogiky na českých vysokých školách na základě výsledků empirického šetření provedeného mezi vyučujícími tohoto předmětu. V první části textu jsou reflektovány trendy ve výuce srovnávací pedagogiky na univerzitách ve světě s odkazy na mezinárodní publikace a projekty. Druhá část je věnována problémům výuky srovnávací pedagogiky v českém prostředí. Nejprve poskytuje stručný vhled do specifik domácího kontextu. Následuje prezentace výsledků empirického šetření, které mapuje současný stav výuky srovnávací pedagogiky na českých univerzitách. V centru pozornosti je postup realizovaného dotazníkového šetření, konstrukce dotazníku a výzkumná zjištění. Ta se vztahují ke koncepci a obsahu předmětu srovnávací pedagogika a podmínkám její výuky. V závěru studie upozorňuje na nevyužité potenciality, formuluje výzvy k diskusi a dalšímu zkoumání výuky srovnávací pedagogiky.
\end{abstract}

Klíčová slova: srovnávací pedagogika, akademický status, studijní programy, učitelé, koncepce předmětu, obsah předmětu, potenciality výuky

Profesor Josef Maňák v dialozích o své životní dráze (srov. Švec, 2003) přiznává, že mezinárodní spolupráce, zahraniční zkušenosti a trvalé srovnávání bylo pro něho silnou motivací podněcující zkvalitnění řešení vlastních problémů. Srovnání s jinými pohledy a progresivními myšlenkami považuje pro české badatele a pedagogy za žádoucí a rozšiřující obzory. Jím zmiňovaná potřeba inspirovat se navzájem a učit se ze zahraničních zkušeností patři k podstatným funkcím srovnávací pedagogiky, jejíž výukou se zabývá tento př́spěvek. Věnuji jej profesorovi Josefu Maňákovi upř́mně a s obdivem k jeho mimořádné osobnosti, šíri odborného záběru, etosu vysokoškolského učitele a vědce, který inspiroval a podporoval generace svých následníků, s přáním, aby tak činil i v dalších letech. 
Srovnávací pedagogika v současnosti je chápána jako významný multidisciplinární obor s rozsáhlým polem, srovnávající vzdělávací systémy a procesy, jejich determinanty a efekty v sociálním kontextu na různých úrovních, včetně úrovně globální.

Srovnávací pedagogika se jako oblast systematického bádání rozvíjí déle než století. Vytvořila rozsáhlou poznatkovou základnu srovnávající, analyzující a kriticky reflektující fenomén vzdělávání v různých zemích, regionech a kulturních okruzích. Srovnávací pedagogika patřri k oborům s vysokou publikační frekvencí, rozsáhlými databázemi a sdílenými nástroji, které umožňují komparace $\mathrm{v}$ diverzifikovaném vzdělávacím prostředí. $\mathrm{V}$ řadě zemí se srovnávací pedagogika institucionalizovala na významných univerzitách. Nedílnou součástí rozvoje tohoto oboru je výuka, která má významnou oporu ve výzkumu a sama se stala předmětem výzkumů a odborného diskurzu. V českém prostředí prokazuje srovnávací pedagogika specifika, která jsou ovlivněna společenským kontextem a vnějšími okolnostmi, v nichž se obor utvářel. K nim patři slabý akademický status a relativně marginální pozornost věnovaná analýze a diskusi o koncepci, obsahu a problémech výuky srovnávací pedagogiky. Záměrem této studie je otevřít otázky výuky srovnávací pedagogiky a zmapovat její současný stav v českém prostředí. V první části studie odkazujeme na vývoj výuky srovnávací pedagogiky na univerzitách ve světě a na její česká specifika. Jde o implicitní srovnání zahraniční a naší domácí situace. Těžiště studie je v její druhé, empirické části, v níž jsou prezentovány výsledky dotazníkového šetření, popisující a analyzující výuku srovnávací pedagogiky na českých vysokých školách. Respondenty šetření byli vysokoškolští učitelé, kteří srovnávací pedagogiku reálně vyučují, jejichž odpovědi a názory lze považovat za expertní. Závěr studie diskutuje problémy a potřeby výuky srovnávací pedagogiky, zvažuje možnosti dalšího výzkumu a aktivit podporujících využití potenciálu srovnávací pedagogiky ve výuce v pedagogických, zejména učitelských oborech.

\section{Trendy ve výuce srovnávací pedagogiky na univerzitách ve světě}

V diskurzech o charakteru a vývoji oboru srovnávací pedagogika upozorňují odborníci na to, že jeho nedílnou součástí je výuka (Halls, 1990; Bray, Adamson, \& Mason, 2007; Váňová, 1998 aj.). Zavádění kurzů srovnávací pedagogiky na univerzitách je považováno za základ institucionalizace oboru, 
jak dokládají historické analýzy konstruování oboru srovnávací pedagogika (Manzon, 2010). I v současnosti má srovnávací pedagogika převážnou část své institucionální základny na univerzitách. Rozvíjí se v univerzitních ústavech a centrech, na katedrách humanitních a sociálních oborů. Soustřed'uje se však zejména na pedagogických fakultách (teacher colleges, schools of education) univerzit. Ke srovnávací pedagogice se hlásí početná komunita vyučujících a studentů. Členové akademické komunity pocházejí z různých disciplín, spojují je společné hodnoty, postoje a zvyklosti, které charakterizují kulturu oboru (podrobněji Becher \& Trowler, 2001). Předmětný obsah výuky má společné jádro, liší se však v preferovaných tématech, metodách či používaných zdrojích dat. Výuka srovnávací pedagogiky má svou historii v univerzitním prostředí, postavení ve studijních programech, mezinárodně využívané učebnice a studijní materiály (srov. Wolhuter et al., 2008a). Univerzity jsou místem primárního setkávání budoucích profesionálních srovnávacích pedagogů s oborem, který budou rozvíjet ve výzkumu i v praktických mezinárodních aktivitách. Absolventi studia srovnávací pedagogiky působí v různých profesích, v mezinárodních organizacích a agenturách zaměřujících se na vzdělávání, i v dalších profesích ke vzdělávání se vztahujících, v pozicích manažerských, projekčních, konzultačních i sociálně podpůrných (Bray, 2007). Mezi priority akademické srovnávací pedagogiky patř́i zařazování srovnávací pedagogiky do studijních programů učitelství. Na komparativním principu jsou koncipovány stěžejní předměty učitelské přípravy. Srovnávací pedagogika prohlubuje teoretické základy studia učitelství, rozvíjí schopnost kriticky reflektovat vlastní vzdělávací systém a podporuje zájem učitelů o dění v oblasti vzdělávání v kontextu mezinárodním (srov. Walterová, 2014).

Srovnávací pedagogika má důležitou úlohu v mezinárodní mobilitě studentů a učitelů. Její význam stoupá zvláště v multikulturním prostředí a v internacionalizovaných vzdělávacích institucích. Srovnávací pedagogika posiluje vnímavost $\mathrm{k}$ alternativám, podporuje učení se ze zkušenosti jiných, přináší inspiraci a kritickou reflexi pedagogické praxe.

Výuka srovnávací pedagogiky na univerzitách, její vývoj a koncepce jsou jedním z témat diskusí a výzkumů. V analýzách oboru srovnávací pedagogika se zdůrazňuje provázanost výzkumné a akademické linie, vliv teorie a srovnávacích výzkumů na proměny obsahu univerzitních kurzů. V epistemologických analýzách se ale poukazuje na paradox chronologického předstihu zavádění kurzů srovnávací pedagogiky do výuky před formováním teoretických základů oboru, což dokládají autoři zabývající se historií srovnávací pedagogiky. 
První doložený kurz srovnávací pedagogiky Srovnávací studium školských systémů byl zaveden na Pedagogické fakultě (Teacher College) Kolumbijské univerzity již v akademickém roce 1899/1990 (Bereday, 1963). Intenzívní rozvoj výuky srovnávací pedagogiky se datuje od 30. let minulého století, kdy byly zaváděny nové studijní programy na prestižních univerzitách, tedy $\mathrm{v}$ době, kdy se již formovaly systematické teoretické základy oboru (podrobněji Walterová, 2006, s. 85). Prestižní univerzity posilovaly srovnávací pedagogiku jako studijní obor. Zejména $v$ 70. a 80 . letech začaly být zaváděny kurzy srovnávací pedagogiky na jiných než pedagogických fakultách v oborech sociálních a humanitních (srov. Wolhuter et al., 2008a).V současné době jsou zavedeny kurzy srovnávací pedagogiky jako systematické akademické disciplíny v řadě oborů na univerzitách všech kontinentů. Mají zpravidla mezinárodní studenty a jsou nabízeny i studentům nepedagogických oborů, jak lze zjistit mj. i z afilace účastníků mezinárodních konferencí a Světových kongresů srovnávací pedagogiky.

V roce 1970 založená Světová rada společností srovnávací pedagogiky formulovala jako jeden ze svých specifických cílů „posilovat výuku srovnávací pedagogiky na univerzitách ve světě“. Prestižní výzkumné univerzity posilovaly srovnávací pedagogiku jako studijní obor převážně v magisterském studiu, v němž studenti získávali kvalifikaci srovnávacích pedagogů. V oboru byli jmenováni profesoři. Výuka srovnávací pedagogiky na univerzitách ve světě byla a je do značné míry závislá na podmínkách, v nichž univerzity pracují, jak dokládají autoři dílčích studií výše uvedené mezinárodní publikace (Wolhuter et al., 2008a). Tak např. zatímco ve Švýcarsku byla v roce 1973 založena profesura srovnávací pedagogiky a ve Španělsku byl obor zaveden již od bakalářského studia, v USA, Kanadě, Velké Británii a Jižní Africe došlo $\mathrm{k}$ fragmentaci a zániku některých studijních programů. Obecným trendem v 80. letech bylo oslabení srovnávací pedagogiky na univerzitách, $\mathrm{v}$ učitelských oborech docházelo k odklonu od akademických disciplín.

V 90. letech je však zaznamenána počínající renesance srovnávací pedagogiky a počátek sílícího trendu přechodu od specializace k integraci srovnávací pedagogiky do pedagogických, sociálních a humanitních oborů, jak potvrzují autoři, kteří se zabývají analýzou vývoje výuky srovnávací pedagogiky (Tickly \& Crossley, 2001). Přelom milénia je označován za revitalizaci srovnávací pedagogiky a uznání jejích potencialit a možností využití ve vzdělávací praxi a vzdělávací politice (srov. Bray, 2003).V současnosti je srovnávací pedagogika 
institucionalizovaná na početných univerzitách ve všech světových regionech v různých formách, které reflektují mnohočetnost modelů a diferenciaci funkcí. Jedná se o následující formy:

- Specializované projekty srovnávací pedagogiky jsou součástí Ph.D. studia na výzkumných univerzitách.

- Studijní programy srovnávací pedagogiky (oborové studium) jsou doloženy na úrovni magisterského i bakalářského studia zejména v zemích, kde má srovnávací pedagogika delší tradici (Velká Británie, USA, Kanada, Japonsko, Čína, Švýcarsko, Norsko, nově Hong Kong a některé africké státy). Tyto programy mají různé názvy. Nejčastější je Srovnávací a mezinárodní pedagogika, Interkulturní a srovnávací pedagogika, k méně častým patří např. Rozvojová a kulturní pedagogika.

Úvodní kurzy srovnávací pedagogiky jsou v současnosti nejvíce frekventované na bakalářské úrovni, o něco méně $v$ magisterském studiu. $V$ některých zemích (Rusko, Kazachstán, Bulharsko apod.) je srovnávací pedagogika povinná v učitelských studijních programech. Některé univerzity nabízejí srovnávací pedagogiku v učitelských studijních programech jako volitelnou, sílí však trend integrovat srovnávací pedagogiku do všech pedagogických disciplín. Absence jednoznačné identity oboru s jasně vymezenými konturami je považována za jeden z podstatných faktorů, který ovlivňuje absorbování nových podstatných témat, reflektujících sociální imperativy determinující vzdělávání, a procesy, které podmiňují vzdělávací změnu.

Výuka srovnávací pedagogiky ustupuje od deskripce celých vzdělávacích systémů, přináší větší množství poznatků $\mathrm{z}$ více vzdělávacích systémů $\mathrm{v}$ prưřezu jejich částmi či zaměřením na srovnání určitého stupně (srovnávací primární pedagogika, srovnávací vysokoškolská pedagogika) či oblasti vzdělávání (např. srovnávací sportovní pedagogika, srovnávací andragogika). Explanace se více zaměřují na objasňování vnějších determinant vzdělávacích systémů, na sociální a kulturní kontexty. Sílí dynamická komparace, orientace na procesy změny, transformace, extrapolace trendů vývoje a důsledky vzdělávacích reforem. Posiluje se reflektivní funkce srovnávací pedagogiky a důraz na porozumění procesům ve vlastním vzdělávacím systému. Analýzy směřují k identifikaci faktorů, které překračují hranice národních vzdělávacích systémů. Progresivní je trend formování kritických přístupů při rozhodování a identifikaci transnacionálního vypůjčování a adaptace vzdělávacích modelů. Aktuálním tématem je globalizace ve vzdělávání, řešení lokálních 
problémů v globálním rámci. Aplikace teorie světového systému a teorií závislosti, efekty neoliberální ekonomiky a mezinárodní srovnávání výsledků žáků patří k aktuálním prioritám revitalizované srovnávací pedagogiky (srov. Walterová, 2014).

V geopolitické orientaci se oslabuje dominance tradičně preferovaných vzdělávacích systémů velkých rozvinutých zemí. Preference se značně liší, stoupá zájem o vzdělávací systémy zemí sousedních či regionálně blízkých, multikulturních, transformujících vzdělávací systémy či produkujících kvalitní vzdělávací výsledky.

Za zmínku stojí také vývoj učebnic a využívání publikací ve výuce srovnávací pedagogiky. Většina učebnic pochází tradičně ze západních zemí a je v angličtině. V posledních letech je zaznamenán nárůst počtu textů určených asijským a africkým studentům. Avšak význam učebnic klesá, dokonce i v úvodních kurzech; konkrétní doklady lze nalézt v projektu CIECAP - Comparative and International Education Societies, viz následující kapitola. Využívají se pouze některé části starších učebnic klasiků při studiu historie oboru a originální překlady dalších textů z francouzštiny, němčiny, italštiny a španělštiny. Podstatnou součást studijních textů tvoří studie z mezinárodních komparatistických časopisů, odborné knihy prestižních autorů a internetové zdroje. V zemích nehovořících světovými jazyky učitelé vytvářejí vlastní učební texty, eventuálně systematické učebnice v mateřském jazyku. Takových učebnic v jazycích národů Evropy, Asie, Afriky a Latinské Ameriky vzniklo po roce 2000 více než stovka. V seznamu všech evidovaných učebnic srovnávací pedagogiky tvoří téměř polovinu (Wolhuter et al., 2008c, s. 345-360).

\section{Mapování vysokoškolské výuky srovnávací pedagogiky}

Výzkumy zabývající se vysokoškolskou výukou srovnávací pedagogiky nejsou četné a jsou relativně nedávného data. K prvnímu zaznamenanému pokusu došlo v polovině 90 . let (Altbach \& Tan, 1995). Autoři provedli dotazníkové šetření a získali data ze 120 institucí. Vytvořili mezinárodní inventář vysokoškolských kurzůำ. Přehled obsahuje údaje o počtech studentů a učitelů,

\footnotetext{
Termín kurz mezinárodně používaný v anglicky psané literatuře zde k označení formy vysokoškolské výuky zachováváme jako výstižnější pro označení programu, event. části vzdělávacího programu na vysokých školách. $\mathrm{V}$ české tradici se používá termín vyučovací předmět vztahující se k organizačním jednotkám obsahu vzdělávání ve školách, včetně škol vysokých. Termín kurz se používá více v doktorských studijních programech.
} 
kvalifikaci učitelů, zařazení kurzů do studijních programů a používaných učebnicích. Výzkum nebyl vyčerpávající, některé světové regiony (Afrika, východní Evropa) byly podceněny. Autoři měli problémy s identifikací a kontaktováním méně známých univerzit, kde se srovnávací pedagogika vyučuje.

V roce 2005 detailnější výzkum, zahrnující však pouze univerzity ve Velké Británii, realizovala Maggie Wilsonová, která využila v té době již existujících webových stránek univerzit. Zvolila kombinaci dvou metod. Nejprve provedla analýzu webových stránek všech univerzit ve Velké Británii a identifikovala postavení srovnávací pedagogiky ve studijních programech. Poté vytvořila záměrný vzorek institucí a rozeslala 67 vyučujícím dotazník. Zjistila mj., že nejfrekventovanější jsou kurzy srovnávací pedagogiky v magisterských studijních programech, ale vzrůstá počet kurzů v bakalářském studiu. Dále zjistila, že $v$ téměř polovině těchto institucí je srovnávací pedagogika jako dimenze zaváděna do jiných disciplín (Wilson, 2005).

V roce 2003 byl iniciován ambiciózní projekt Archiv vysokoškolských kurzů srovnávací pedagogiky, který má umožnit analýzu kurzů srovnávací pedagogiky na vybraných univerzitách ve světových regionech. Na konferenci CIES (Comparative and International Education Societies) v New Orleansu referovala skupina komparatistů, vedená profesorem Ervinem Epsteinem, o výzkumu, který uskutečnilo Centrum srovnávací pedagogiky ve spolupráci s Asociací studentů srovnávací a mezinárodní pedagogiky na univerzitě v Chicagu (Loyola University). Prezentace měla značný ohlas a iniciovala založení tematické skupiny, která organizuje sekci Vyučování srovnávací pedagogice na konferencích CIES. Referát byl publikován v časopise Comparative Education Review (Cook, Hite, \& Epstein, 2004). Následně WCCES (World Council of Comparative Education Societies) přijala projekt vytvoření databáze vysokoškolských kurzů srovnávací pedagogiky jako jeden ze svých podporovaných projektů. Databáze Comparative and International Education Course Archive Project (CIECAP) je otevřená a dostupná on-line. ${ }^{2}$ Obsahuje podrobné informace o 76 kurzech na 31 univerzitách v USA a Kanadě, Evropě, Asii a Africe. Databáze obsahuje kurzy z prestižních amerických univerzit a univerzit ve Velké Británii, Švédsku, Norsku, Estonsku, Číně, Indii, Austrálii a Jižní Africe. Očekávají se příspěvky dalších univerzit, aby bylo dosaženo globálního pokrytí univerzitních center srovnávací pedagogiky ve světě.

2 http://www.luc.edu/cce/ciecap.shtml 
Záměrem autorů je provést srovnávací analýzu na základě dat z tohoto archivu. Podmínkou pro realizaci záměru je systematické budování databáze. Ta má předepsanou strukturu a požadavky na informace, které musí popis kurzu obsahovat, v jaké formě mají být údaje uváděny, což je předpoklad pro provedení srovnávací analýzy.

Databáze může být také využívána jako inspirace pro ty, kteř́i chtějí kurzy srovnávací pedagogiky zavést nebo inovovat. Participanti ukládají do databáze reference o instituci, studijním programu, obsahu a typu kurzu, včetně jmen vyučujících. Dále jsou povinné bibliografické údaje publikací vyučujících, používaných učebnic, knih a časopisů, event. vybraných statí v časopisech. Sylabus kurzu zahrnuje popis cílů, obsahu (moduly, bloky, témata) a organizace kurzu, včetně používaných metod, požadavků na výstupy a hodnocení studentů.

I když se jedná o základní úvodní kurzy srovnávací pedagogiky, je pozoruhodná variabilita modelů předmětu, témat a forem výuky. Výrazná je profilace kurzů, respektující odlišné tradice institucí, v nichž jsou kurzy realizovány, vazby na výzkumné zaměření vyučujících a publikace, s nimiž studenti pracují. Všechny kurzy mají však společné jádro a jsou budovány systematicky jako akademická disciplína. Jádro zahrnuje historii oboru, odkazy na funkce srovnávací pedagogiky, teoretický a metodologický základ, odkazy na vztahy k jiným disciplínám. Orientují studenty také na klíčová témata a problémy praxe.

Archiv byl cenným zdrojem informací, využitých $\mathrm{v}$ této studii. Projekt CIECAP byl též inspirací pro výzkumné šetření, které jsme realizovali v českém prostředí.

Jiným typem výzkumu zaměřeného na srovnávací pedagogiku v globální dimenzi byl projekt WCCES (2005-2008) - Srovnávací pedagogika na univerzitách ve světě. Výstupem jeho poslední fáze je stejnojmenná publikace (Wolhuter et al., 2008a). Zaměřuje se na historické okolnosti počátků srovnávací pedagogiky a její současné problémy na univerzitách ve světových regionech, které byly zvoleny jako základní jednotky analýzy podle politickogeografického modelu, který zavedl do srovnávací pedagogiky Halls (1990). Srovnání „srovnávacích pedagogik“ na univerzitách ve 41 zemích se zaměřuje na klíčové otázky srovnávací pedagogiky v pěti světových regionech (Evropa, Severní Amerika, Latinská Amerika, Asie, Afrika). 
Narativní forma př́ípadových studií neumožňuje kvantitativní srovnání. I když se o ně autoři v závěrečné kapitole pokoušejí, čísla jsou nespolehlivá a nepovažuji je ani pro daný typ výzkumu za relevantní. Kvalitativní analýza prŕṕpadových studií však odhaluje detailní obrazy proměn oboru ve světě jako dosud částečně skrytou mozaiku srovnávacích pedagogik. Dokládá, že neexistuje jedna srovnávací pedagogika, ale mnohočetné srovnávací pedagogiky (viz též Cowen, 1990; Pampanini, 2005; Epstein, 2008). Poskytuje dosud nejdetailnější globální obraz proměn oboru v charakteristikách infrastruktury a postavení srovnávací pedagogiky v kurikulu pregraduálních a postgraduálních studijních programů. Zkoumá cíle, funkce, metody a učebnice srovnávací pedagogiky i rozdíly $\mathrm{v}$ chronologii institucionalizace oboru v univerzitním prostředí.

Přes chronologické rozdíly v jednotlivých zemích se autoři srovnávací závěrečné kapitoly pokusili o rozlišení vývojových fází a identifikaci hlavních trendů v jejich rámci (s. 323-326). Raná fáze (1900-1910) byla obdobím hledání a iniciativou jednotlivců, zakladatelů oboru. V klasické fázi srovnávací pedagogiky (1920-1940) již srovnávací pedagogika pod vlivem zakladatelských univerzit existovala na několika univerzitách v USA a Anglii a dalších evropských zemích. Za důležitý akt je považována konference v roce 1931, které předsedal Paul Monroe z Kolumbijské univerzity a která přijala usnesení zavádět kurzy srovnávací pedagogiky na pedagogických fakultách. Na konci 30. let už tyto kurzy byly zavedeny na několika desítkách univerzit v USA, Anglii, Německu, Švýcarsku, Bulharsku, Chorvatsku, Norsku, Japonsku, Číně, Mexiku, Kubě a Brazílii. Vyučovali zde odborníci dnes slavných jmen, mezi nimi Isaack Kandel, James Russel, John Dewey, Friedrich Schneider, Jean Piaget a další. V období expanze srovnávací pedagogiky (1950-1970) se již rozšíŕila výuka na všechny kontinenty. 80. a 90. léta minulého století byla obdobím oslabování a odklonu od akademické srovnávací pedagogiky. Od konce 90. let došlo k revitalizaci oboru a posilování výuky srovnávací pedagogiky, vnitřně diferenciovaného oboru s různými modely a funkcemi.

Kritická reflexe výstupů projektu WCCES otevírá v závěrečné kapitole (Wolhuter et al., 2008b, s. 319-340) také diskuzi o pojetí srovnávací pedagogiky na univerzitách $\mathrm{v}$ současnosti. 
Autoři rozlišují tři odlišná paradigmata:

- pedagogické systémové: orientuje srovnávací pedagogiku na vnitřní problémy vzdělávacích systémů;

- sociologické: zaměřuje srovnávací pedagogiku na vztahy mezi společností a vzděláváním, tj. na aspekty sociální, politické, ekonomické, geografické, demografické a filozoficko-náboženské ve vztahu ke vzdělávání;

- komparatisticko-průřezové: zaměřuje srovnávací pedagogiku na problémy vzdělávacích systémů v sociálním kontextu průřezově.

\section{Výuka srovnávací pedagogiky v českém prostředí}

Srovnávací pedagogika v českém univerzitním prostředí se sice rozvíjí celé století, avšak vzhledem k historickým peripetiím a závislosti na vnějších podmínkách výuka srovnávací pedagogiky nemá tradici srovnatelnou se zahraničními univerzitami. Na českých univerzitách sice působili akademici, kteří ke srovnávací pedagogice přispívali již v klasickém období a produkovali cenné srovnávací publikace (Kádner, Příhoda, Uher, Hessen a další), avšak srovnávací pedagogika nebyla předmětem výuky. Ve druhé polovině minulého století, kdy se prudce rozvíjí srovnávací pedagogika na řadě prestižních univerzit ve světě, $v$ českém kontextu pod politickým a ideologickým tlakem stagnuje. Krátkodobá existence Katedry srovnávací pedagogiky na Fakultě sociálních věd Univerzity 17. listopadu, rozvoj srovnávací pedagogiky na Katedře pedagogiky Filozofické fakulty a Ústavu učitelského vzdělávání Univerzity Karlovy v Praze, kde působily významné osobnosti (Kotásek, Pařízek, Singule a jiní) zůstala epizodou. V 80. letech byla vydána publikace dvou autorů, působících na tehdejší brněnské Univerzitě Jana Evangelisty Purkyně, Úvod do srovnávací pedagogiky (Jůva \& Liškař, 1982), schválená Ministerstvem školství jako vysokoškolská učebnice pro studenty fakult připravujících učitele. Měla poskytovat budoucím učitelům a pedagogickým pracovníkům základní orientaci ve srovnávací pedagogice, označené autory jako „relativně nová pedagogická disciplína“ (zdůraznila E. Walterová). Přes odborné kvality byla publikace typickým produktem normalizace (podrobně Walterová, 2006, s. 269-270).

Radikální změna politické orientace po roce 1989 aktivizovala odbornou komunitu a rozvoj srovnávací pedagogiky v univerzitním prostředí. $\mathrm{Na} \mathrm{Pe}-$ dagogické fakultě Univerzity Karlovy $\mathrm{v}$ Praze $\mathrm{v}$ nově zrrízeném Ústavu 
pedagogických a psychologických výzkumů dokonce vzniklo specializované pracoviště, Oddělení srovnávací pedagogiky. To však díky následujícím organizačním změnám po pěti letech své existence zaniklo, i když srovnávací pedagogika zůstává trvalou součástí odborného zaměření pracoviště, dnes Ústavu výzkumu a rozvoje vzdělávání. Srovnávací pedagogika se rozvíjí na dalších vysokoškolských pracovištích, zejména na katedrách pedagogiky Filozofické fakulty a Pedagogické fakulty Univerzity Karlovy v Praze, na Filozofické fakultě Masarykovy Univerzity v Brně a na Pedagogické fakultě Univerzity Palackého v Olomouci.

Zavádění výuky srovnávací pedagogiky na českých univerzitách bylo spojeno s transformací vzdělávání. V první fázi, v 90 . letech, silným impulzem byla potřeba předávat budoucím učitelům a pedagogickým pracovníkům informace o trendech ve vzdělávacích systémech $\mathrm{v}$ rozvinutých demokratických zemích. Otevřel se prostor pro srovnávací výzkumy a vstupy do mezinárodních projektů. Srovnávací pedagogika přinášela mnoho nových poznatků o vzdělávání ve světě a upozorňovala na nezbytnost kritického pohledu na české i zahraniční vzdělávání (podrobně Walterová, 2006, s. 271-280). Na výše zmíněných univerzitách působily osobnosti, které iniciovaly vznik Sekce srovnávací pedagogiky Československé pedagogické společnosti v 60. letech a po období útlumu dostali možnost utvářet koncepci výuky a prosazovat srovnávací pedagogiku do studijních programů. Vedle již renomovaných akademiků (Kotásek, Singule, Pařízek) participovali na rozvoji srovnávací pedagogiky další mladší osobnosti (Nezvalová, Průcha, Rabušicová, Rýdl, Váňová M., Walterová a jiní). Postupně se výuka srovnávací pedagogiky rozširrila na další univerzity, zejména po nástupu nové generace v první dekádě 21. století. Od druhé poloviny 90 . let jsou na některých českých univerzitách realizovány srovnávací výzkumy, které ovlivnily utváření strategie žádoucí vzdělávací reformy. Česká republika se účastní velkých mezinárodních výzkumů, které jsou „mnohdy jediným zdrojem relevantních informací o různých aspektech fungování vzdělávacího systému" (Potužníková, Lokajíčková, \& Janík, 2014, s. 213). Také četnost publikací není zanedbatelná. Publikační produkce ve srovnávací pedagogice $\mathrm{v}$ posledních dvaceti letech přesahuje stovku titulů (Ježková, 2013; Průcha, 2014).

Česká srovnávací pedagogika na univerzitách však nedosáhla postavení uznávaného oboru, má slabý akademický status a rozptýlenou institucionální základnu v různých organizačních rámcích. Je jednak součástí akademických a výzkumných pracovišt', ale také rozvojových a evaluačních institucí, jejichž 
kmenovým oborem není srovnávací pedagogika. Srovnávací pedagogika není akreditována a nelze ji studovat jako obor, nelze se v ní habilitovat a získat profesuru. Kritická reflexe vývoje české srovnávací pedagogiky je spíše dílem iniciativních jednotlivců či skupin (srov. Greger, 2014) než předmětem soustavného zájmu oborové komunity. Také výuka srovnávací pedagogiky zůstává mimo hlavní proud odborného zájmu pedagogické komunity a výzkumu.

První výzkumná sonda vztahující se k výuce srovnávací pedagogiky (Walterová, 2006) byla iniciována ze zahraničí. K účasti v mezinárodním projektu, který mapoval srovnávací pedagogiku v učitelském vzdělávání (Popov et al., 2006), byla vyzvána i Česká republika (Walterová, 2006). Vzhledem $\mathrm{k}$ absenci dat o výuce srovnávací pedagogiky v učitelském vzdělávání v České republice byla výzkumná sonda zaměřena na cíle, koncepci a aktuální problémy srovnávací pedagogiky v učitelském vzdělávání. V kontextu vývoje srovnávací pedagogiky byly identifikovány a analyzovány modely výuky srovnávací pedagogiky a sylaby př́slušných předmětů na sedmi pedagogických a dvou filozofických fakultách. V této výzkumné sondě byly identifikovány tři varianty výuky srovnávací pedagogiky: (a) povinný předmět v oborovém studiu pedagogiky, (b) komponent v povinných úvodních kurzech obecné pedagogiky ve studiu učitelství, (c) vybraná témata v různých specializovaných disciplínách. Výsledky výzkumné sondy poukázaly na důsledky diskontinuity ve vývoji české srovnávací pedagogiky a nezakotvenost disciplíny v akademickém prostředí, limitující její zavádění do studijních programů učitelství. V dalších letech se pedagogický výzkum výukou srovnávací pedagogiky nezabýval. Aktuální data nebyla k dispozici ani při reedici publikace o srovnávací pedagogice na univerzitách ve světě, v níž byla studie z roku 2006 pouze přetištěna (Walterová, 2008).

Rozšiřování výuky srovnávací pedagogiky na další univerzity v České republice je progresivním trendem $\mathrm{v}$ posledním desetiletí. $\mathrm{V}$ akreditovaných studijních programech pedagogických oborů a učitelství je však srovnávací pedagogika zařazována jako předmět, aniž by jeho koncepce, statut a obsah byl podroben analýze a odborné diskusi.

Vzhledem k autonomii vysokých škol a relativní kurikulární volnosti není zařazení či nezařazení tohoto předmětu ani problémem, kterým by se speciálně zabývala akreditační komise. Posuzování studijních programů se soustřed'uje více na formální kritéria, která má předmět splňovat. Jeho zařazení a realizace ve výuce zůstává $\mathrm{v}$ kompetenci navrhovatele příslušných kateder i jednotlivých vyučujících. Z neformálních diskusí je zřejmé, že učitelé 
srovnávací pedagogiky pocitují určitou izolovanost, absenci odborného diskurzu a relativně nízkou podporu, či dokonce rezistenci kateder při rozhodování o zařazení, statutu a obsahu předmětu.

Stav výuky srovnávací pedagogiky na českých univerzitách zůstával nezmapovaným, její problémy nereflektovány a ponechány víceméně na vyučujících. Relevance srovnávací pedagogiky a absence dat o stavu její výuky v prostředí českých univerzit byly podstatným stimulem k realizaci výzkumu, kterým se zabýváme v následující části této studie.

\section{Dotazníkové šetření}

Cílem dotazníkového šetření bylo zmapovat současný stav výuky srovnávací pedagogiky na vysokých školách v České republice. Výzkum se soustředil na podstatné charakteristiky předmětu srovnávací pedagogika, jeho koncepci, obsah, prostředky a subjekty výuky i na identifikaci problémů, s nimiž se vyučující setkávají. Zde uvádíme problémové okruhy a hlavní výzkumné otázky:

- Institucionální základna výuky srovnávací pedagogiky. Na kterých vysokých školách a fakultách se předmět srovnávací pedagogika vyučuje?

- Postavení predmětu srovnávací pedagogika ve studijních programech. Ve kterých typech studijních programů je srovnávací pedagogika zařazena jako předmět? Jaký má tento předmět statut?

- Pojetí předmětu srovnávací pedagogika. Jak je předmět koncipován? Liší se jeho koncepce realizovaná ve studijních programech pedagogických a učitelských oborů?

- Obsah předmětu srovnávací pedagogika. Které podstatné okruhy a témata utvářejí obsah předmětu srovnávací pedagogika?

- Geopolitická orientace srovnávací pedagogiky. Na které světové regiony či země a jejich vzdělávací systémy se výuka srovnávací pedagogiky orientuje? Které země jsou preferované a frekventované?

- Prostředky a metody výuky $v$ predmětu srovnávací pedagogika. Které metody jsou ve výuce aplikovány? Preferují vyučující tradiční formy vysokoškolské výuky či využívají metody specifické a inovativní? Jaké prostředky jsou využívány $\mathrm{k}$ posílení motivace studentů a hodnocení výstupů předmětu? 
- Problémy výuky srovnávací pedagogiky. S jakými problémy se vyučující předmětu srovnávací pedagogika setkávají ve své praxi nejčastěji? Jaké podmínky a které bariéry ovlivňují kvalitu výuky a přitažlivost srovnávací pedagogiky pro studenty?

- Učitelé srovnávací pedagogiky. Kdo předmět srovnávací pedagogika vyučuje? Jakou mají učitelé předmětu graduaci a odbornou specializaci? Co je motivuje k výuce srovnávací pedagogiky?

\subsection{Postup výzkumu}

Výzkumné šetření bylo realizováno v roce 2013 ve dvou fázích. V první fázi (leden-únor) byly identifikovány fakulty vysokých škol v ČR, na nichž existují pracoviště (katedry a ústavy; dále jen pracoviště), v jejichž gesci jsou pedagogické obory (pedagogika, primární pedagogika, sociální pedagogika, andragogika) a u nichž lze předpokládat, že realizují akreditované studijní programy, v nichž může být srovnávací pedagogika zařazena jako předmět výuky. Identifikace byla provedena pomocí vyhledávání na webových stránkách fakult, kde byly získány také př́slušné adresy. Byl vytvořen seznam 34 pracovišt', 18 fakult a 11 univerzit v ČR.

Následně byl vytvořen adresář vedoucích těchto pracovišt', kteří byli osloveni dopisem. $V$ něm byli informováni o záměru výzkumného šetření a požádáni o zodpovězení otázky: Vyučuje se na vašem pracovišti (katedře, ústavu) srovnávací pedagogika? Odpověd' nabízela pouze dvě varianty: ANO x NE. $\mathrm{V}$ případě kladné odpovědi byli vedoucí požádáni o sdělení jména vyučujícího / jmen vyučujících s kontaktní adresou. $\mathrm{V}$ případě negativní odpovědi byli vedoucí pracovištt také požádáni o zaslání odpovědi, aby byla zajištěna zpětná vazba a v další fázi nebylo opomenuto žádné pracoviště, jehož studijní programy srovnávací pedagogiku potenciálně mohou obsahovat.

Obdrželi jsme 19 odpovědí $A N O$ (včetně pracoviště autorky tohoto článku), 5 odpovědí $N E$. 10 oslovených vedoucích pracovišt' neodpovědělo ani po opakované výzvě. $V$ těchto př́ípadech nezbývá než předpokládat, že odpověd' by zněla $N E$, byla však považována oslovenými vedoucími pracovišt' za nadbytečnou.

Ve druhé fázi výzkumného šetřeníbylo osloveno 19 akademických pracovníků, kteří byli uvedeni vedoucími pracovišt' jako vyučující srovnávací pedagogiky. Byl tak získán soubor devatenácti respondentů, který představoval aktuální úplný soubor vyučujících srovnávací pedagogiky na vysokých školách v ČR. 
Těmto devatenácti vyučujícím byl rozeslán dotazník (viz níže) a současně s odpověd'mi byli respondenti požádáni o poskytnutí sylabů předmětu srovnávací pedagogika, který vyučují. Dotazník vyplnilo (v období dubenkvěten) 16 vyučujících, kteří zaslali sylaby nebo odkazy na jeho dostupnou webovou prezentaci, takže návratnost $84,21 \%$ byla relativně vysoká.

\subsection{Dotazník}

Dotazník byl určen výhradně akademickým pracovníkům, kteří aktuálně srovnávací pedagogiku vyučují. Při jeho konstruování jsme se částečně inspirovali výzkumnými šetřeními, která byla zaměřena na mapování a analýzu výuky srovnávací pedagogiky v zahraničí (Altbach \& Tan, 1995; Wilsonová, 2005; CIECAP aj.). Vzhledem k nízkému počtu respondentů dotazník kombinoval zavřené a otevřené otázky. $V$ celkovém počtu 30 položek byl jejich poměr zhruba 1:1. Dotazník se obracel k respondentům jako odborníkům, kteří mohou být nápomocni při mapování současného stavu a problémů výuky srovnávací pedagogiky. $V$ úvodu dotazníku byl zdůrazněn význam srovnávací pedagogiky a možnost přispění respondentů k rozvoji oboru u nás s využitím zkušeností nepočetné skupiny vyučujících, v níž každý hlas má svůj význam. Dotazník byl rozesílán elektronicky, stejnou formou byly odesílány odpovědi respondentů. Termín pro odesílání dotazníku, převážně limitovaný jednoměsíční lhůtou od zaslání, byl později prodloužen o jeden měsíc, kdy byla v několika případech výzva k vyplnění opakována, až ve finále bylo získáno 16 dotazníků, s nimiž se dále pracovalo.

Dotazník měl pět částí. První část byla zaměřena na postavení a status předmětu srovnávací pedagogika ve studijních programech. Ve druhé části se dotazník zaměřil na postoje vyučujících ke srovnávací pedagogice a jejich motivaci. Třetí část se věnovala celkovému pojetí předmětu, jeho koncepci a struktuře. Nejrozsáhlejší čtvrtá část dotazníku se zaměřila na obsah předmětu, hlavní tematické okruhy, geopolitickou orientaci a preference vzhledem ke světovým regionům a zemím. $\mathrm{V}$ páté části dotazník zjišt'oval prostředky a metody výuky, používané informační zdroje, možnosti využití získaných poznatků studenty. Ve dvou volných výrocích v závěru dotazníku se respondenti vyjadřovali k problémům a překážkám, s nimiž se při výuce srovnávací pedagogiky setkávají. Měli také prostor pro vyjádření komentářu a námětů k dalším problémům, které nebyly v dotazníku zachyceny. 
Navíc byla do dotazníku zařazena podrobná identifikační část, která obraz reality výuky srovnávací pedagogiky doplnila o charakteristiky vyučujících. Získány byly údaje o kvalifikaci a pracovním zařazení respondentů, délce působení na vysoké škole i době (počtu let), po kterou respondenti srovnávací pedagogiku vyučují, a konečně, také o „kurikulárním kontextu“, v němž respondenti aktivně působí, tj. které další předměty vyučují.

Dotazník byl anonymní, přesto však všichni respondenti uvedli svou afilaci k instituci a pracovišti, na němž působí, i svá plná jména. Ačkoliv většina respondentů souhlasila s eventuálním zveřejněním svého jména, anonymitu zachováme, avšak uvádíme, $v$ př́padech nezbytných a pro prezentaci výsledků relevantních, odkaz na instituci.

\section{Výzkumná zjištění}

Dotazníkové šetření poskytlo určitý obraz aktuálního stavu výuky srovnávací pedagogiky na českých vysokých školách. Výzkumná zjištění jsou založena na reflexi vyučujících, hlavních aktérů této výuky. Uvádíme je proto v jiné posloupnosti, než byly sestaveny otázky dotazníku. Nejprve se zaměříme na afilaci vyučujících $\mathrm{k}$ univerzitám a fakultám, čímž poskytneme přehled institucí, kde se výuka srovnávací pedagogiky realizuje. Poté zařazujeme charakteristiky respondentů a charakteristiky kontextu, $v$ němž působí, tedy kdo a v jakých podmínkách srovnávací pedagogiku vyučuje. Následují zjištění, vztahující se ke koncepci, obsahu a dalším konkrétním problémům výuky srovnávací pedagogiky, které jsou již vlastní reflexí respondentů, ovlivněnou jejich zkušeností, názory a postoji. ${ }^{3}$

\subsection{Institucionální př́slušnost respondentů}

V tabulkách 1 a 2 uvádíme afilaci respondentů k univerzitám a fakultám.

Tabulky 1 a 2 dokládají, že srovnávací pedagogika se aktuálně vyučuje na jedenácti fakultách sedmi veřejných univerzit. Všechny tyto fakulty patří k fakultám připravujícím učitele. Z devíti současných pedagogických fakult pak je to pouze pět, na nichž se vyučuje srovnávací pedagogika.

3 Vzhledem k nepočetnému souboru respondentů uvádíme kvantitativní údaje pouze v př́padech, které považujeme za relevantní pro popis současného stavu. 
Tabulka 1

Př́slušnost respondentů $k$ univerzitám

\begin{tabular}{lc}
\hline \multicolumn{1}{c}{ Název univerzity } & Počet vyučujících \\
\hline Univerzita Karlova v Praze & 6 \\
Univerzita Palackého v Olomouci & 3 \\
Masarykova Univerzita v Brně & 2 \\
Ostravská univerzita & 2 \\
Univerzita Hradec Králové & 1 \\
Univerzita Pardubice & 1 \\
Univerzita Tomáše Bati ve Zlíně & 1 \\
\hline
\end{tabular}

Celkem 7 univerzit

Celkem 16 vyučujících

Tabulka 2

Příslušnost respondentů $k$ fakultám

\begin{tabular}{lcc}
\hline \multicolumn{1}{c}{ Typ fakulty } & Počet fakult & Počet vyučujících \\
\hline Pedagogická fakulta & 5 & 9 \\
Filozofická fakulta & 2 & 3 \\
Fakulta humanitní & 2 & 2 \\
Teologická fakulta & 1 & 1 \\
Př́rodovědecká fakulta & 1 & 1 \\
\hline Celkem & 11 & 16 \\
\hline
\end{tabular}

\subsection{Vyučující srovnávací pedagogiky}

Kdo srovnávací pedagogiku na českých vysokých školách vyučuje? Obraz aktuálního stavu poskytly podrobné identifikační údaje respondentů. Jejich charakteristiky uvádíme nejprve v přehledných tabulkách 3, 4, 5. 
Tabulka 3

Pracovní zařazení/kategorie vyučujících

\begin{tabular}{lc}
\hline \multicolumn{1}{c}{ Kategorie } & Počet respondentů \\
\hline Profesor & 5 \\
Docent & 3 \\
Odborný asistent & 6 \\
Asistent & 1 \\
Externí učitel & 1 \\
\hline
\end{tabular}

Celkem 16

Tabulka 4

Délka působení na vysoké škole

\begin{tabular}{lc}
\hline \multicolumn{1}{c}{ Počet let } & Počet respondentů \\
\hline více než 20 let & 4 \\
více než 10 let & 5 \\
$5-10$ let & 4 \\
$1-5$ let & 3 \\
\hline & Celkem 16 \\
\hline
\end{tabular}

Tabulka 5

Počet let výuky srovnávací pedagogiky

\begin{tabular}{lc}
\hline \multicolumn{1}{c}{ Počet let } & Počet respondentů \\
\hline více než 20 let & 4 \\
více než 10 let & 3 \\
$5-10$ let & 6 \\
$1-5$ let & 3 \\
\hline & Celkem 16 \\
\hline
\end{tabular}

Přehledy pracovního zařazení a délky působení na vysoké škole dokumentují, že srovnávací pedagogiku vyučují převážně akademičtí pracovníci vyšších kategorií působící na vysoké škole delší dobu. Polovina z nich jsou profesoři a docenti, ve druhé polovině převažují odborní asistenti. $S$ akademickou graduací vyučujících přirozeně koresponduje doba působení na vysoké škole, která u většiny, tj. devíti vyučujících, přesahuje deset let. Také mladší vyučující nejsou zpravidla úplní začátečníci. Zjištění, že ve skupině vyučujících pře- 
važují ti, kteří vyučují srovnávací pedagogiku déle než deset let, včetně čtyř, kteří tento předmět vyučují již déle než dvacet let, souvisí s postupným zaváděním předmětu srovnávací pedagogika do studijních programů. To začalo v 90. letech v pedagogických oborech na Univerzitě Karlově v Praze na pedagogické i filozofické fakultě, na Masarykově Univerzitě v Brně na filozofické fakultě, později i na pedagogické fakultě a na Palackého Univerzitě v Olomouci zprvu na pedagogické fakultě. Titíž vyučující, dnes již profesoři a docenti, kteří výuku srovnávací pedagogiky zaváděli, působí v oboru i v současnosti. Výraznějšího zavádění do studijních programů se srovnávací pedagogika dočkala v první dekádě 21 . století, kdy se vyučujícími tohoto předmětu stávali př́slušníci nastupující mladší generace akademických pracovníků. Pozornost zaslouží zjištění, že v sylabech předmětu srovnávací pedagogika uváděná studijní literatura odkazuje na tituly, jejichž autory jsou pracovníci s vyšší akademickou graduací, kteří se oboru věnují delší dobu a výzkumně a publikačně se profilují. U pracovníků s vyšší akademickou graduací převažuje pojetí předmětu jako systematické vědecké disciplíny. Začínající vyučující uvádějí zpravidla koncepci předmětu garantovanou zkušenějším pracovníkem s vyšší graduací.

Vjakém oboru získávali vyučující vysokoškolskou kvalifikaci a vyšší akademickou graduaci? Tato otázka nás zajímala především proto, že ve srovnávací pedagogice u nás graduaci nelze získat. Vyučující srovnávací pedagogiky mohou mít odlišné předchozí vzdělání a kvalifikaci. S jednou výjimkou uvedli respondenti učitelskou kvalifikaci, přičemž pouze osm, tedy polovina z nich, absolvovala magisterské studium oboru pedagogika, další studium učitelství všeobecně vzdělávacích předmětů, dva studium učitelství pro první stupeň (respondenti uvádějí jako „primární pedagogika“). V oboru vyšší akademické graduace (Ph.D., docent, profesor) již převažuje pedagogika, kterou uvedlo 13 vyučujících, dva uvedli andragogiku a jeden neuvedl.

Zajímavý a značně diverzifikovaný obraz poskytly údaje o kurikulárním kontextu vyučujících srovnávací pedagogiky, tj. které další předměty vyučují. Zajímalo nás, zda lze identifikovat dominantní, event. standardní kombinace předmětů, které jsou preferovány při tvorbě výukových úvazků zahrnujících srovnávací pedagogiku. Vzhledem k tomu, že se jednalo o volnou otázku, respondenti uváděli výčet všech předmětů, které vyučují v různých akreditovaných studijních programech. Tyto předměty nemají ani standardizované názvy, natož obsahy, což při zpracování odpovědí bylo problémem. Provedli 
jsme proto nejprve třídění předmětů na tři skupiny: (a) skupina předmětů, které odpovídají základním disciplínám oboru pedagogika a zpravidla mají ve studijních programech status povinných předmětů (A); (b) předměty, které odpovídají aplikovaným a hraničním disciplínám, převážně se statutem povinně volitelných předmětů (B); (c) předměty specializované, představující pestrou škálu zpravidla výběrových předmětů (C). Odpovědi poskytují orientační vhled do možných kombinací předmětů vyučovaných respondenty, součástí jejichž úvazku je srovnávací pedagogika. Standardní kombinace nebyla identifikována. Vyskytuje se více variant kombinací se základními a aplikovanými disciplínami. Jde o kombinace s didaktikou (obecnou, školní, primární), celkem se vyskytla šestkrát. Další variantou je kombinace s obecnou pedagogikou, vyskytla se třikrát. Podobně také kombinace s teorií výchovy, sociologií výchovy nebo sociologií vzdělání či vzdělávací politikou. Ve třech př́padech byla uvedena kombinace s metodologií pedagogiky. Pouze v jednotlivých případech byly uváděny předměty jako filozofie výchovy či předměty spadající do oblasti školského managementu a pedagogické evaluace. $\mathrm{V}$ případě výuky srovnávací andragogiky se tento předmět vyskytuje v kombinaci s teorií celoživotního vzdělávání a gerontopedagogikou, v případě předškolní pedagogiky v kombinaci s předmětem pedagogika rodiny.

Ve skupině volitelných předmětů, kde nebylo možno identifikovat frekventované, ale spíše specifické varianty kombinací, jsou uváděny v individuálních případech dle různého zaměření vyučujících takové předměty jako genderová studia, multikulturní výchova, výchova ke globální odpovědnosti, zdravý životní styl, evropské vzdělávací programy a projekty, pedagogická diagnostika, osobnost učitele a další.

Kombinace předmětů vyučovaných spolu se srovnávací pedagogikou nemohou vyučující zcela ovlivnit svou osobní volbou. Jsou podřízeny reálné personální situaci konkrétního pracoviště, které realizuje výuku dle akreditovaných studijních programů a jím odpovídajícího rozvržení do studijních plánů. To je také jedním z faktorů odlišné motivace respondentů k výuce srovnávací pedagogiky, která se liší v jednotlivých případech, mj. i v závislosti na akademickém statusu, postavení na pracovišti a míře vyhraněnosti odborného zaměření. Proč tedy vlastně respondenti vyučují srovnávací pedagogiku, co je jejich hlavní motivací a čím byla tato volba ovlivněna? V odpovědích na blok otázek vztahujících se k motivaci respondentů převažuje důraz na potřebu integrovat mezinárodní dimenzi do odborného zaměření, možnost využití mezinárodních zkušeností a posílení mezipředmětových vazeb. Zatímco 
u skupiny zkušenějších akademických pracovníků, vyučujících srovnávací pedagogiku zpravidla více než deset let, je deklarována osobní motivace, dlouhodobý zájem o předmět, který je osobní volbou a patří k odborným prioritám respondentů, u mladších vyučujících je výuka srovnávací pedagogiky vnímána více jako plnění povinností vyučovat předmět přidělený vedoucím pracoviště. Pouze v ojedinělých případech respondenti považují výuku srovnávací pedagogiky za možnost využívat výsledky vlastních výzkumů. To není překvapivé, protože srovnávací výzkumy v prostředí českých vysokých škol nejsou frekventované (srov. Průcha, 2014). Naopak poněkud překvapivé bylo pro nás zjištění, že motivace vyučovat srovnávací pedagogiku nesouvisí s mírou obliby předmětu u studentů.

\subsection{Zařazení předmětu Srovnávací pedagogika ve studijních programech}

Předmět je zařazován do studijních programů převážně pod názvem Srovnávací pedagogika. Ojediněle se uvádí také pod alternativními názvy Komparativní pedagogika, Srovnávací andragogika, Evropská studia, Evropská dimenze vzdělávání. Vyskytuje se i název Primární pedagogika 5, jehož obsah odpovídá předmětu Srovnávací pedagogika (jedná se o studijní program akreditovaný na Pedagogické fakultě Ostravské univerzity v Ostravě, který používá specifickou terminologii Katedry primárního a alternativního vzdělávání. ${ }^{4}$

Zjištovali jsme, ve kterých typech studijních programů, s jakým statutem, eventuálně dotací, je srovnávací pedagogika zařazena. $Z$ údajů získaných dotazníkem jsme sestavili tabulku 6, která přehledně dokumentuje současný stav zařazení předmětu $\mathrm{v}$ akreditovaných studijních programech pedagogických oborů a oborů zaměřených na vzdělávání.

4 Dále budeme používat společný název předmětu Srovnávací pedagogika, pokud nebude nezbytné upozornit na specifika předmětu označeného jiným názvem. 
Tabulka 6

Předmět Srovnávací pedagogika ve studijních programech ${ }^{5}$

\begin{tabular}{lcc}
\hline Typ studijního programu & \multicolumn{2}{c}{ Typ předmětu $^{6}$} \\
& Povinný & Povinně volitelný \\
\hline Bc. studium oboru pedagogika/andragogika & 1 & \\
Bc. studium oborů se zaměřením na vzdělávání & 2 & 2 \\
Mgr. studium oborů Pedagogika & 6 & \\
(Andragogika/Sociální pedagogika, Management vzdělávání) & 3 & $1^{7}$ \\
Mgr. učitelství 1. stupně & 5 & \\
Mgr. učitelství VVP & 3
\end{tabular}

Předmět srovnávací pedagogika je tedy zařazován především do studijních programů magisterského studia oboru pedagogika, event. dalších pedagogických oborů, jako povinný. V magisterském studiu učitelství je srovnávací pedagogika zařazována především na fakultách, které mají akreditované studijní programy oboru pedagogika, zatímco na fakultách, které oborové studium pedagogiky nemají, je to spíš výjimečné. V našem šetření se jednalo pouze o jednu pedagogickou fakultu a dále o fakultu teologickou a fakultu humanitní $\mathrm{s}$ akreditovanými studijními programy učitelství. $\mathrm{V}$ obou posledních př́padech vyučují srovnávací pedagogiku renomovaní odborníci, déledobě se zabývají srovnávací pedagogikou a publikují zásadní práce v této disciplíně. Zařazení srovnávací pedagogiky do studijního programu je v těchto případech motivováno nepochybně i odborností vyučujících. Zařazení srovnávací pedagogiky do bakalářských studijních programů lze považovat za výjimečné.

Časová dotace předmětu Srovnávací pedagogika není shodná. Předmět je většinou jednosemestrální s dotací dvě hodiny týdně, zakončený v oborovém studiu pedagogiky zkouškou. Také v dalších studijních programech je zakončen převážně zkouškou, výjimečně zápočtem. Pouze v jednom případě má dotaci tři hodiny týdně, $v$ jiném jednom př́padě je výjimečně dvousemestrální. V kombinovaném studiu se jedná zpravidla o 4-6hodinový blok. Co se týče počtu kreditů, předmět je oceňován různě, dvěma až pěti kredity.

V doktorském studiu oboru pedagogika, které bylo $\mathrm{v}$ době šetření akreditováno na pěti fakultách (3 pedagogické, 2 filozofické), kurz Srovnávací pedagogiky byl doložen pouze na jedné fakultě (Pedagogická fakulta UK) s dotací 32 hodin jako volitelný, zakončený zkouškou.

5 Předmět může mít alternativní název (viz výše).

6 Číslo udává počet zjištěných programů, v nichž je zařazen předmět Srovnávací pedagogika.

7 Předmět je zařazen jako povinný do volitelného modulu. 


\subsection{Pojetí předmětu Srovnávací pedagogika}

Výuka srovnávací pedagogiky nemá ustálenou koncepci, má více modelů a řadu variant $\mathrm{v}$ zahraničí $\mathrm{i} u$ nás. Jsou do značné míry ovlivněny typem studijního programu, konstrukcí sylabu i osobností garanta předmětu a vyučujícího (nemusí se jednat o jednu a tutéž osobu). V dotazníku byly respondentům předloženy obecnější, typologicky odlišné modely pojetí předmětu. Z nich měli respondenti vybrat ten, jenž nejvýstižněji charakterizuje koncepci předmětu, který vyučují:

1. Předmět je koncipován systematicky jako vědecká disciplína.

2. Předmět je koncipován konstruktivisticky, orientuje se primárně na vybraná témata reflektující aktuální problémy v českém vzdělávacím systému v komparaci s jejich řešením v zahraničí, zejména s těmi, kteří mohou poskytovat inspiraci a napomáhat porozumění trendům a problémům ve vzdělávacích systémech.

3. Předmět se zaměřuje převážně na zahraniční vzdělávací systémy, jejich popis a analýzy vnitřních souvislostí pedagogických jevů a faktů.

Obě první varianty jsou v souboru respondentů prezentovány více méně rovnoměrně $(7: 6)$, třetí spíše obě doplňuje jako východisko a zdroj informací.

První model, systematicky koncipovaný předmět, je preferován ve studijních programech oborového studia pedagogiky/andragogiky. Uvádí do historie, teorie a metodologie srovnávací pedagogiky, seznamuje s podstatnými pojmy a paradigmaty, institucionální a informační bází, zabývá se trendy ve vývoji vzdělávacích systémů ve světě. Srovnává vývoj vzdělávání v zahraničí s domácí situací.

Druhý, konstruktivisticky koncipovaný model, převažuje ve studijních programech učitelství a má více obsahových variant. I když zpravidla stručně uvádí do studia srovnávací pedagogiky jako oboru, orientuje se především na příslušnou úroveň vzdělávacího systému (primární, sekundární) a na vybrané aktuální problémy důležité pro praxi a budoucí profesi. Zaměřuje se na učitelskou profesi, školní vzdělávání, kurikulum, hodnocení žáků apod. K odborné koncepci inklinuje předmět v oboru sociální pedagogika, má v úvodní části systematický základ. Reflektuje podmínky a problémy související s budoucí profesí vychovatele, výchovného poradce, sociálního pracovníka. Jak uvádí vyučující, koncepce předmětu a adekvátní model se v tomto oboru postupně vylad'uje. 
Třetí přístup, který je v zahraničí již opouštěn, plní spíše funkci zdroje informací o vzdělávání v zahraničí a je východiskem pro průřezové srovnávání. Může využívat dnes existující rozsáhlé databáze národních př́ípadových studií popisujících detailně vzdělávací systémy a jejich součásti. Tento přístup doplňuje obě zmíněné koncepce, systematickou i konstruktivistickou. Jako preferovaný byl uveden pouze třemi respondenty.

Z komentářů respondentů k pojetí předmětu lze soudit, že ve výuce jsou využívány různé kombinace všech tří uvedených koncepcí, i když v pojetí předmětu lze identifikovat preferenci typologicky odlišných obecnějších modelů, jak bylo uvedeno výše ${ }^{8}$.

\subsection{Obsah předmětu Srovnávací pedagogika}

Respondenti byli vyzváni, aby uvedli pět tematických okruhů, které považují za jádro obsahu předmětu Srovnávací pedagogika, který vyučují. Poznatky získané z dotazníku byly rozšířeny analýzou sylabů předmětu, které respondenti k dotazníku připojili.

Uváděné podstatné tematické okruhy, které lze považovat za jádro obsahu, se liší vzhledem k preferované koncepci předmětu $\left.{ }^{9}\right)$. $V$ případech preferujících systematickou koncepci předmětu jako disciplíny dominují následující tematické okruhy: teorie a metodologie srovnávací pedagogiky, funkce srovnávací pedagogiky, infrastruktura srovnávací pedagogiky, vývoj a typologie vzdělávacích systémů, trendy vývoje vzdělávání ve světě, v Evropě a v České republice $\mathrm{v}$ komparativní perspektivě. $\mathrm{V}$ preferované konstruktivistické koncepci předmětu lze identifikovat obsahové dominanty dle frekvence tematických okruhů. K nim patři následující: využití srovnávací pedagogiky v řízení školství a v pedagogické praxi, práce se zdroji dat, srovnávání úrovní vzdělávacích systémů (dle zaměření studijního programu), učitelská profese a vzdělávání učitelů v zahraničí, mezinárodní výzkumy výsledků žáků a jejich využití, alternativy a inovace ve vzdělávání. V nejméně preferované koncepci

$8 \quad$ V této poznámce reaguji na komentář redakce Pedagogické orientace k rukopisu mé studie. $\mathrm{V}$ něm byl vysloven dotaz, jaké paradigma lze identifikovat ve výuce srovnávací pedagogiky u nás. $\mathrm{Z}$ odpovědí respondentů to nelze zjistit, explicitně nebyla taková otázka položena. Z přiložených sylabů předmětu lze však usuzovat, že převažuje orientace na vnitřní problémy vzdělávacích systémů, což odpovídá pedagogicko-systémovému paradigmatu, jednomu ze tř́, které rozlišují autoři publikace (Wolhuter et al., 2008a), na niž odkazuji v textu této studie výše - v kapitole 2.

9 Okruhy nejsou respondenty označovány zcela identicky. Zde používáme sjednocující názvy, které vystihují obsahový i terminologický charakter uváděných okruhů. 
předmětu, $v$ níž je jádro obsahu založeno na analýze vzdělávacích systémů, byly identifikovány dva odlišné typy podstatných tematických okruhů. V prvním jsou uváděny vzdělávací systémy, na něž se výuka v synchronní dimenzi soustřed'uje následovně: vzdělávací systém České republiky, vzdělávací systém Německa, vzdělávací systémy sousedních zemí, vzdělávací systémy anglicky mluvících zemí. Ve druhém typu jsou podstatné tematické okruhy vymezeny vzhledem $\mathrm{k}$ tradici řešení problémů vzdělávání takto: německá tradice, francouzská tradice, anglická tradice, ruská tradice, italská tradice. Toto obsahové jádro bylo vymezeno ve shodě s koncepcí pracoviště zaměřeného na primární a alternativní pedagogiku. Jak již bylo uvedeno výše, při preferování jedné ze tří koncepcí, je využíváno jejich kombinací. V preferované systematické koncepci nechybí aplikace a příklady práce s mezinárodními databázemi a nástroji (ISCED, indikátory kvality), srovnávací analýzy typologicky odlišných vybraných vzdělávacích systémů a srovnávací prưřezové analýzy řešení aktuálních problémů vzdělávání. $\mathrm{V}$ preferované konstruktivistické koncepci má předmět poskytnout alespoň vhled do metodologické a institucionální báze oboru, seznámit s typologií srovnávacích výzkumů. Pro ilustraci jsme z odpovědí celého souboru respondentů sestavili přehled nejfrekventovanějších tematických okruhů, považovaných pro výuku srovnávací pedagogiky za podstatné (číslo v závorce uvádí, kolikrát daný tematický okruh respondenti uváděli. Analýza vybraných vzdělávacích systémů (16), využívání mezinárodních databází (11), mezinárodní organizace zabývající se vzděláváním (9), mezinárodní výzkumy výsledků vzdělávání (8), učitelská profese, vzdělávání učitelů (8), řízení školství a vzdělávací politika (6), kurikulum (5), integrace a inkluze (5), reformní, inovativní a alternativní koncepce (4), multikulturalita (4), evropská dimenze vzdělávání (3). Následující zařazená témata se pak vyskytují jen ojediněle: negramotnost jako celosvětový problém, srovnání trendů ve vzdělání v rozvinutých a rozvojových zemích, proměny školy a školního vzdělávání, vzdělávání zdravotně postižených, resocializační instituce a péče v zahraničí.

V předmětu srovnávací pedagogika lze tedy identifikovat určité obsahové jádro a varianty, které jsou ovlivněny preferovanou koncepcí, oborem studia i zaměřením vyučujících.

\subsection{Geopolitická orientace ve výuce Srovnávací pedagogiky}

Na které světové regiony, státy a země se výuka srovnávací pedagogiky zaměřuje nejčastěji? Které země a jejich vzdělávací systémy jsou předmětem 
srovnávání? Z odpovědí respondentů a textu sylabů je zřejmé, že jednoznačně preferovaným regionem je Evropa, zvláště členské země Evropské Unie, následovaná severní Amerikou, zejména USA, méně často Kanada, dále jihovýchodní Asie, především Japonsko a prudce se rozvíjející země, jako je Čína, méně Indie a ostatní státy tohoto regionu. Malá, spíše ojedinělá pozornost je zaměřená na rozvíjející se region Afriky a Latinské Ameriky, nezmíněny byly země Karibiku. Okrajovými jsou Arabské státy, opomenuta zůstává Austrálie, která byla uvedena pouze $v$ jednom případě. Z evropských zemí jsou nejčastěji předmětem srovnávání vzdělávací systémy sousedních států, především Německo a Rakousko, následované Polskem, méně často Slovensko. Dále pak dominují, se stejnou četností jako země sousední, velké země s rozvinutými vzdělávacími systémy, zejména Velká Británie, především Anglie, následovaná Francií. Frekventované jsou skandinávské země. Relativně menší pozornost je věnována vzdělávání v Rusku a v zemích východní Evropy. Pobaltské a další postsovětské státy nebyly zmiňovány. Ojediněle se vyskytuje Švýcarsko a Itálie, byly vícekrát zaznamenány země Beneluxu, s výjimkou Nizozemska, které bylo uvedeno pouze v jednom prŕpadě. Španělsko a Portugalsko, podobně jako další Středomořské státy, nebyly zaznamenány.

Ve výběru států ke srovnání lze identifikovat více kriterií. Jde o volbu států blízkých s typologicky podobnými vzdělávacími systémy, dále o volbu států s typologicky odlišnými vzdělávacími systémy, především členské země OECD, a také o volbu států, které prokazují nadprůměrné výsledky v mezinárodním srovnání výsledků žáků (PISA, TIMSS, PIRLS).

Repertoár srovnávaných zemí je značně ovlivněn, dle odpovědí respondentů, také osobním zájmem a zkušeností vyučujícího, zájmem a jazykovým vybavením studentů. Má své limity, je omezen dostupností informačních zdrojů a také jazykovými možnostmi studentů. Naopak rozšíření repertoáru srovnávaných zemí umožňuje relativní volnost, kterou mají studenti při volbě témat referátů a seminárních prací (viz níže).

\subsection{Prostředky a metody výuky}

Ve výuce srovnávací pedagogiky, dle údajů většiny respondentů, je relativně málo času na interaktivní metody. Podstatnou část tvoří přednášky, vzhledem k nízké časové dotaci (předmět je dotován zpravidla 2 hodinami týdně, v poměru $1 / 1$ přednáška/seminář). Ve třech př́padech se výuka omezuje výhradně na přednášky, do nichž jsou zařazovány diskusní bloky nebo jsou přednášky koncipovány interaktivně. Zajímavou inovací je zařazování vy- 
stoupení zahraničních odborníků, které uvedlo 8 respondentů. Podnětným a aktivizujícím prvkem je zařazování zahraničních studentů do výuky srovnávací pedagogiky, které je však spíše výjimečné, vzhledem k dosavadnímu nedostatku takových př́ležitostí $\mathrm{v}$ daných oborech studia. Na rozdíl od zahraničních univerzit, kde se kurzů srovnávací pedagogiky účastní mezinárodně pestré skupiny, jsou u nás převážně jazykově a národnostně homogenní skupiny českých studentů.

Podstatnou část výuky v seminářích tvoří referáty a prezentace seminárních prací. Seminární práce vypracovávají studenti, s jednou výjimkou, ve všech př́padech zahrnutých do našeho výzkumu. Témata seminárních prací si zpravidla volí sami studenti, vyučující je schvalují. Méně často jsou témata seminárních prací vypisována vyučujícím. Zvláštním př́ípadem je vypsání společného zastřešujícího tématu, $v$ němž si studenti volí svá dílčí témata. Témata seminárních prací lze zařadit do následujících typů: (a) komparace vybraného vzdělávacího systému s českým s důrazem na rozdílný společenský kontext, (b) komparace studenty zvolených aspektů vzdělávání v ČR a v zahraničí, (c) komparace řešení problému aktuálního v českém vzdělávání a cíleně vybraných zemích, které problém úspěšně řeší.

Při zpracování seminárních prací je kladen důraz na práci s mezinárodními databázemi a zahraničními zdroji. Seminární práce rozšiřují repertoár srovnávaných zemí a podporují motivaci a zájem o srovnávací pedagogiku.

Dále ve výuce srovnávací pedagogiky jsou využívány zkušenosti studentů z programů mobility, což lze považovat za jednu z potenciálních možností zvýšení atraktivity a motivace studentů. Závisí však na příležitostech studentů se těchto programů zúčastnit. Využívání této možnosti uvedlo devět respondentů.

\subsection{Studijní literatura a učebnice}

V dotazníku nebyla položena otázka vztahující se ke studijní literatuře. Lze však rekonstruovat literaturu doporučovanou studentům v sylabech, který dokresluje informace o pojetí předmětu, jeho obsahu a tematických preferencích. $\mathrm{V}$ celkovém pohledu se seznamy literatury vyznačují značnou diverzitou v počtu (uváděno je 5-11 titulů) i v charakteru. Zahrnují kromě odborných knih také skripta, soubory případových studií vybraných vzdělávacích systémů, programové a politické dokumenty, statistické a datové přehledy, zprávy z mezinárodních výzkumů výsledků žáků, časopisy a odka- 
zy na webové portály. Bylo by zajímavé zjištovat, podle jakých kritérií jsou publikace a další zdroje informací vybírány i jak jsou tyto zdroje využívány studenty. Takové otázky však přesahují rámec této studie. Zde se omezím na dílčí zjištění, která umožnila v celém zkoumaném souboru identifikovat některé charakteristiky vztahující se k oporám předmětu srovnávací pedagogika. Především je třeba uvést, že se značně liší charakter doporučované literatury $\mathrm{v}$ předmětu koncipovaném systematicky jako vědní disciplína a v konstruktivisticky koncipovaném předmětu orientovaném na vybrané problémy a témata. $\mathrm{V}$ druhém př́padě doporučená literatura obsahuje více specifických titulů vztahujících se k vybraným tématům - např. alternativní pedagogické koncepce a školy, učitelská profese, vzdělávání znevýhodněných žáků, kurikulum či evaluace. Výběr titulů, které se k danému tématu vztahují, přitom nemusí být primárně komparativní.

V předmětu koncipovaném jako vědecká disciplína jsou uváděny především publikace základní a přehledové reflektující teoretické a metodologické problémy srovnávací pedagogiky a témata podstatná pro komparativní analýzu vzdělávacích systémů. Nejfrekventovaněji jsou uváděny publikace: Průcha (1999 a 2006) celkem jedenáctkrát a Walterová (2004) celkem devětkrát. Z dalších je to teoreticky orientovaná publikace Váňové (1998) celkem pětkrát a Rýdla (2003) celkem čtyřikrát. V pěti případech publikace tohoto typu uvedeny nejsou. Uváděna jsou však skripta, která je do určité míry nahrazují, ve třech případech je uvedena učebnice (Štverák, 1999). Dalším typem jsou soubory převážně deskriptivních studií vybraných vzdělávacích systémů. Překvapivě frekventované jsou publikace staršího data, které vznikly v 90. letech. Mezi nimi se vyskytuje nejčastěji publikace Ježkové a Walterové (1997) celkem desetkrát, dále Ježkové (1996) celkem osmkrát, Váňové (1994) celkem pětkrát; ojediněle pak i další (Nezvalová, 1998; Váňová, 1994, 1997). Překvapení vzbuzují zejména odkazy na starší publikace z 80. let Jůva a Liškař (1982) a edice Školství v zahraničí vydávaná Ústavem školských informací. Odkazy na aktualizované popisy a komparace vzdělávacích systémů lze předpokládat u doporučovaných webových portálů (Eurydice, OECD, UNESCO, NAEP), které jsou uvedeny v polovině sylabů bez bližší specifikace. Konkrétní odkazy na datové přehledy typu Key data on education in Europe či Education at a glance jsou uvedeny pouze ve třech případech. Mezi dokumenty, uváděnými ojediněle, byly uvedeny Bílé knihy o vzdělávání (EU, 1997 a ČR, 2001), Delorsova zpráva UNESCO, u nás pod názvem Učení je skryté bohatství (1997), a některé legislativní a další programové dokumenty domácí. 
Nebyl nalezen žádný odkaz na konkrétní monotematické číslo časopisu nebo časopiseckou studii. Odkazy na tituly mezinárodních časopisů srovnávací pedagogiky (Comparative Education Review, Compare, Oxford Comparative Education Studies aj.) byly uvedeny ve čtyřech případech. Frekventovanější jsou odkazy na zprávy z mezinárodních výzkumů výsledků žáka IEA (TIMSS, PIRLS) a OECD (PISA), uvedeny celkem šestkrát.

Vhled do seznamů studijní literatury k předmětu srovnávací pedagogika přináší několik obecnějších zjištění a otázek. Doporučovány jsou knižní tituly a skripta i staršího data, a to $\mathrm{v}$ češtině. $\mathrm{V}$ celém souboru sylabů $\mathrm{v}$ bakalářském a magisterském studiu se vyskytly pouze dva tituly v angličtině, jeden $\mathrm{v}$ němčině. Prestižní mezinárodní publikace, které jsou u nás recenzované a citované v odborné literatuře, studentům doporučovány nejsou. Aktuální problémy a mezinárodní diskurzy ve srovnávací pedagogice rozvíjené se tak českým studentům dostávají zprostředkovaně v reflexi českých autorů, pokud vůbec. Otázkou je, zda by měly být zahraniční komparativní publikace překládány, nebo by studenti měli být více motivováni k četbě cizojazyčné literatury a zdokonalování odborného jazyka.

Seznamy literatury zahrnují často starší tituly, obsahující nezřídka informace již neaktuální, ne-li zavádějící. Vzdělávací systémy se proměňují, dynamicky se rozvíjí srovnávací pedagogika a odborný diskurz v oboru. Neměla by se průběžně revidovat a aktualizovat také studijní literatura?

Zkušenosti vysokoškolských učitelů ukazují, že současní studenti stále více pracují s elektronickými médii. Nová média sice poskytují aktuální informace relativně rychle, zároveň však narůstá problém, jak s nimi pracovat, jak se v nich orientovat a vybírat ty relevantní a spolehlivé. Měly by seznamy doporučené literatury reflektovat i elektronická média a poskytnout studentům konkrétnější vodítko při výběru relevantních a ověřených elektronických zdrojů informací?

\subsection{Podstatné problémy uváděné vyučujícími}

Nejčastěji uváděným problémem je nedostatečná jazyková vybavenost studentů. Studenti pracují převážně s českými publikacemi a materiály, cizí jazyky mohou využívat při práci s internetovými zdroji informací a mezinárodními databázemi, veřejně na internetu dostupnými. Ač jsou studenti schopni běžné komunikace v cizím jazyce, mají obtíže s porozuměním odborným textům i orientací v cizojazyčných zdrojích a databázích. Na druhém 
místě jsou uváděny problémy spojené s výukovými materiály, vysokou cenou zahraničních publikací a jejich nedostatkem v češtině, zejména ohledně metodologie srovnávací pedagogiky a systematických publikací zabývajících se zahraničními vzdělávacími systémy. ${ }^{10}$

Jako další problémy jsou uváděny následující: heterogennost studijních oborů účastníků výuky, absence nebo nedostatečnost systematických základů oboru pedagogika, na něž by mohla výuky srovnávací pedagogiky navazovat, izolovanost předmětu a absence vazeb na základní pedagogické disciplíny, vnímání předmětu jako okrajového a nepodstatného pro budoucí profesi, nízká časová dotace neumožňující specializaci a individualizaci výuky. Zmiňován je také nedostatek příležitostí pro praktické mezinárodní aktivity, eventuálně exkurze studentů a nedostatečnost všeobecné znalosti zahraničních kontextů, kultury a historie.

Potěšující jsou však některé komentáře respondentů, kteří se ve volném závěrečném výroku vyjadřují k možnostem využití poznatků ze srovnávací pedagogiky nejen $v$ jiných předmětech, $v$ diplomových pracích ${ }^{11}$, ale zejména v osobnostním rozvoji a kultivaci studentů, v posílení kritického myšlení a obraně proti xenofobii. Respondenti doporučují zavádět komparativně koncipovaná témata také $\mathrm{v}$ jiných předmětech a posílit akademický status předmětu srovnávací pedagogika.

\section{Závěrečná rozvaha}

Vývoj a stav vysokoškolské výuky srovnávací pedagogiky je aktuálním tématem, diskutovaným ve světě, zatímco v českém prostředí nepatří k problémům, kterým je věnována patřičná pozornost. Jak bylo doloženo v přehledové části této studie, historické okolnosti a specifické podmínky neumožnily u nás do 90 . let minulého století rozvíjet srovnávací pedagogiku jako plnohodnotný obor. Chronologická diskontinuita způsobila, že výuka srovnávací pedagogiky se postupně na českých vysokých školách začala zavádět až v souvislosti s procesem transformace vzdělávání.

10 Toto zjištění je poněkud zarážející. Česká literatura tohoto druhu existuje sice v omezené míře, ale zahraničních titulů je nepřehledné množství, v němž se musí zorientovat především vyučující a doporučit relevantní tituly studentům. Přehledy doporučené literatury v sylabech předmětu by zasloužily revizi a aktualizaci.

11 Osm respondentů uvedlo př́klady úspěšně obhájených diplomových prací ze srovnávací pedagogiky, přesto, že pro studenty je zpracování komparativního tématu považované za obtížné a volí raději témata snazší. 
Koncepce a realizace výuky srovnávací pedagogiky v českém prostředí postrádá oporu ve výzkumu a v kritické reflexi problémů na rozdíl od systematického budování teoretických základů a mezinárodně vedeného diskurzu, který výuku srovnávací pedagogiky ve světě mapuje a analyzuje.

V dotazníkovém šetření, inspirovaném zahraničními výzkumy a mezinárodními diskusemi, byl současný stav výuky srovnávací pedagogiky na českých vysokých školách zmapován, byly identifikovány jeho problémy a nevyužitý potenciál. Respondenty dotazníkového šetření byli akademičtí pracovníci vyučující srovnávací pedagogiku v současnosti. Údaje získané v dotazníkovém šetření byly doplněny údaji získanými ze sylabů předmětu srovnávací pedagogika, zařazeného do akreditovaných studijních programů pedagogických oborů. Výsledkem je získání množství nových poznatků a současně i řada otázek intrapředmětových i rámec předmětu srovnávací pedagogika přesahujících, vztahujících se ke konstrukci kurikula pedagogických, zejména učitelských oborů. Některá zjištění vyhlížejí možná triviálně, avšak v situaci, kdy studijní programy jsou v kompetenci jednotlivých fakult a kateder, kdy koncepce kurikula, a zejména obsah předmětů výuky, včetně srovnávací pedagogiky, vzniká bez obecnějšího rámce, lze je považovat za přínosné a obohacující poznání fenoménů, kterým u nás dosud nebyla ve výzkumu a odborné diskusi věnována pozornost.

Doloženo bylo zařazení srovnávací pedagogiky do studijních programů učitelských a dalších pedagogických oborů na jedenácti fakultách sedmi univerzit v České republice, převážně jako povinného předmětu v magisterském studiu učitelství. Otázkou zůstává, jaké okolnosti vedly fakulty s akreditovanými studijními programy stejného typu k tomu, že se na nich srovnávací pedagogika nevyučuje. Pozornost budí zjištění, že na Karlově univerzitě v Praze má srovnávací pedagogika relativně silnou pozici, její výuka je zavedena na třech fakultách, na nichž tento předmět vyučuje šest akademických pracovníků, zatímco na čtyřech regionálních univerzitách, které mají pedagogické fakulty, výuka srovnávací pedagogiky zavedena není. Přitom se jedná o fakulty, jejichž působnost zasahuje do př́ihraničních lokalit a euroregionů, kde nabývá na významu přeshraniční spolupráce škol, výměny žáků a studentů a dokonce plnění školní docházky v sousední zemi. V této souvislosti vzniká také otázka, proč a zda má, či nemá být předmět srovnávací pedagogika do studijních programů, zejména učitelství prvního stupně a učitelství všeobecně vzdělávacích předmětů, zařazován a jaké okolnosti vedly fakulty se studijními programy tohoto typu k tomu, že se u nich srovnávací pedagogika nevyučuje. Existují způsoby, které tuto absenci kompenzují? 
Závažná zjištění se týkají koncepce a obsahu předmětu srovnávací pedagogika. $V$ oborovém studiu převažuje koncepce předmětu jako systematické disciplíny kombinovaná s konstruktivistickou, která je preferovaná $\mathrm{v}$ učitelských oborech, kde se výuka zaměřuje více na vybrané aktuální problémy praxe a vzdělávací politiky. Preferovaná koncepce ovlivňuje zásadně zaměření a obsah předmětu. I když lze identifikovat určité obsahové jádro v tématech, která vyučující považují za důležitá, diverzita obsahu je značná. Měl by mít předmět srovnávací pedagogika vymezen nějaký standardní obsah?

Podstatnou otázkou přesahující intrapředmětový rámec je postavení srovnávací pedagogiky v kurikulu. Kdy by měla být zařazována? Má plnit propedeutickou funkci či funkci předmětu integrujícího? Respondenti inklinují k podpoře integrativní, zastřešující funkce a zařazení do vyšších ročníků s předpokladem již formované kognitivní a metodologické báze. Otázkou je, zda koncepce a obsah kurikula př́íslušných oborů zajištujue vytváření takového základu, na nějž mohou vyučující srovnávací pedagogiky navazovat.

Zvláštní okruh problémů souvisí s vyučujícími samotnými. Pokud srovnávací pedagogiku vyučuje zkušenější učitel s vyšší akademickou graduací, výraznější profilací odborného zájmu, může se srovnávací pedagogice věnovat intenzívněji, což dokládá i publikační produkce takových vyučujících. Jejich publikace jsou uváděny v doporučené literatuře i u jiných vyučujících. Mladší vyučující s vyššími výukovými úvazky, kterým je předmět zpravidla přidělován, si vztah k němu postupně utvářejí. Jaké by se jim mělo dostat podpory, když u nás není srovnávací pedagogika studijním oborem ani specializací? Navíc má v úvazcích jen malý podíl. $\mathrm{V}$ dotazníkovém šetření byla identifikována široká škála kombinací vyučovaných předmětů u vyučujících srovnávací pedagogiky, nějaká standardní a typická vazba na jiné vyučované předměty nebyla identifikována. Zde je třeba také poznamenat, že vyučující srovnávací pedagogiky pracují často v izolaci, bez potřebné podpory, předání know-how či možnosti konzultací se zkušenějším kolegou, a to i když má předmět garanta, který se však na srovnávací pedagogiku nespecializuje.

Podstatným problémem, který je v českém prostředí známý, ale ne diskutovaný, je nedostatečně rozvinutý srovnávací pedagogický výzkum a srovnávací pedagogika jako obor vůbec. Nepropojenost výuky s výzkumem, identifikovaná na většině fakult, kde se srovnávací pedagogika vyučuje, je na rozdíl od výuky na zahraničních univerzitách zřetelná. Velké srovnávací výzkumy typu PISA, TIMSS, PIRLS apod. se realizují v mimouniverzitním prostředí. Výraznější zaměření na srovnávací pedagogický výzkum a publikační produkci 
ve srovnávací pedagogice prokazují především pražské fakulty, zejména Pedagogická fakulta. Na dalších fakultách je srovnávací pedagogický výzkum a publikace $\mathrm{v}$ tomto oboru záležitostí několika jednotlivců. Nedostatečná výzkumná zkušenost oslabuje odborný potenciál těch vyučujících, kteří se odkazují na sekundární zdroje informací a na publikace charakteru kompendií a skript, uváděných v doporučené literatuře. Mezi doporučenými tituly se téměř nevyskytují cizojazyčné publikace, vyjma odkazů na webové zdroje, které jsou však velmi obecné. Důvody, které respondenti uvádějí, se týkají malé dostupnosti cizojazyčné literatury. Za podstatný problém je považováno nedostatečné jazykové vybavení studentů, obtížnost získávání kvalitní, cenově nedostupné cizojazyčné literatury a málo př́ležitostí pro studenty získat mezinárodní zkušenosti. Bylo by řešením vytvoření nové vysokoškolské učebnice srovnávací pedagogiky, i když i v češtině existuje řada kvalitních titulů, vycházejí časopisecké studie a recenze zahraničních publikací, na něž se lze odkazovat? Pak je ale otázkou, proč se odkazy na tyto tituly a zdroje uvádějí jen v některých sylabech, zatímco v jedné třetině sylabů nikoliv.

Jak bylo uvedeno výše, výuka srovnávací pedagogiky $\mathrm{v}$ českém prostředí má značné, dosud ne plně využité rezervy. Má potenciál pro osobnostní i profesní motivaci studentů, žijících a v budoucnu profesně působících v podmínkách multikulturní a globalizované společnosti. $\mathrm{V}$ pedagogických a učitelských oborech by měl být tento potenciál rozvíjen se zvýšenou naléhavostí. Srovnávací pedagogika přispívá k rozvoji kritického myšlení, poznávání jiných kontextů a podob vzdělávání, umožňuje lépe pochopit podstatu pedagogických fenoménů. Vede k vnímání a porozumění jinakosti i k poučené reflexi vzdělávání v domácím prostředí.

Otázky, které otevřel náš výzkum, intrapředmětové i přesahující rámec předmětu srovnávací pedagogika, jsou výzvou k hlubšímu zkoumání, které by mělo navázat na zjištění současného stavu, zabývat se identifikovanými problémy a hledáním způsobů, jak v podmínkách našich vysokých škol lépe využít komparační potenciál. Podobně jako v jiných akademických oborech jej může posílit také širší odborná diskuse. ${ }^{12}$

12 Prvním krokem byla již realizovaná panelová diskuse o výuce srovnávací pedagogiky, která na daný výzkum navázala a zabývala se některými zde otevřenými otázkami. Účastnili se někteří respondenti dotazníkového šetření a další odborníci. Zpráva o panelové diskusi bude uveřejněna v Pedagogické orientaci 1/2015. 


\section{Literatura}

Altbach, P. G., \& Tan, E. G. (1996). Programs and centres in comparative and international education: A global inventory. Buffalo: Graduate School of Education Publications.

Becher, T., \& Trowler, P. (2001). Academic tribes and territories: Intellectual enquiry and the culture of disciplines. Buckingham: The Society for Research into Higher Education and Open University Press.

Bereday, G. (1963). James Russel's syllabus of the first academic course in comparative education. Comparative Education Review, 7(2), 189-196.

Bray M., Adamson, M., \& Mason, M. (Eds.). (2007). Comparative education research. Approaches and methods. Hong Kong: Springer.

Bray, M. (Ed.). (2003). Comparative education. Continuing traditions, new challanges, and new paradigms. Dordrecht: Kluwer Academic Publishers.

Bray, M. (2007). Actors and purposes in comparative education. In M. Bray, B. Adamson, \& M. Mason (Eds.), Comparative education research. Approaches and methods. (s. 15-38). Hong Kong: Springer.

Comparative and international education course archive project. New York: University at Albany, State University of New York. Dostupné z http://www.luc.edu/cce/ciecap.shtml

Cook, B. J., Hite, S. J., \& Epstein, E. H. (2004). Discerning trends, contours and boundaries in comparative education. A survey of comparativists and their literature. Comparative Education Review, 48(2), 123-149.

Cowen, R. (1990). The national and international impact of comparative education infrastructures. In W. D. Halls (Ed.), Comparative education: Contemporary issues and trends (s. 321-352). Paris: Jessica Kinsley.

Epstein, E. H. (2008). Crucial benchmarks in the professionalization of comparative education. In C. Wohlhuter, N. Popov, M. Manzon, \& B. Leutwyler (Eds.), Comparative education at universities world wide (s. 9-24). Sofia: BES.

Greger, D. (Ed.). (2014, v tisku). Srovnávací pedagogika: Proměny a výzvy. Praha: PedF UK.

Halls, W. D. (Ed.). (1990). Comparative education: Contemporary issues and trends. London: Jessica Kinsley Publishers \& UNESCO.

Ježková, V., \& Walterová, E. (1997). Vzdělávání v zemích Evropské unie. Praha: PedFUK.

Ježková, V. (2013). Srovnávací pedagogika v bibliografickém přehledu. In V. Ježková (Ed.), Srovnávací pedagogika (s. 11-40). Praha: PedF UK.

Jůva, V., \& Liškař, Č. (1982). Úvod do srovnávací pedagogiky. Praha: SPN.

Manzon, M. (2010). Comparative education: The construction of a field. Hong Kong: Springer.

Národní program rozvoje vzdělávání v České republice: Bílá kniha. (2001). Praha: Ústav pro informace ve vzdělávání - Tauris.

Nezvalová, D. (1997). Školství v edukačně vyspělých zemích. Olomouc: UP.

Pampanini, G. (2005). Critical essay on comparative education. Catania: CUECM.

Popov, N., Wolhuter, C., Keller, C., \& Kysilka, M. (2006). Comparative education and teacher training. Sofia: BES.

Potužníková, E., Lokajíčková, V., \& Janík, T. (2014). Mezinárodní srovnávací výzkumy školního vzdělávání v České republice. Pedagogická orientace, 24(2), 185-221.

Průcha, J. (1999). Vzdělávání a školství ve světě. Základy mezinárodní komparace. Praha: Portál. 
Průcha, J. (2006). Srovnávací pedagogika. Praha: Portál.

Průcha, J. (2009). Srovnávací pedagogika. In J. Průcha (Ed.), Pedagogická encyklopedie (s. 686-690). Praha: Portál.

Průcha, J. (2014, v tisku). Česká srovnávací pedagogika: Přehled produktů let 1992-2012. In D. Greger (Ed.), Srovnávací pedagogika: proměny a výzvy. Praha: PedF UK.

Rýdl, K. (2003). Inovace školských systémů. Praha: ISV.

Štverák, V. (1999). Obecná a srovnávací pedagogika. Praha: Karolinum.

Švec, V. (2003). Životní cesta jako proces výchovy a sebevýchovy. Dialogy s Josefem Maňákem nejen o pedagogice. Brno: KONVOJ.

Tickly, L., \& Crossley, M. (2001). Teaching comparative and international education: A framework for analysis. Comparative Education Review, 45(4), 561-580.

Učení je skryté bohatství: zpráva Mezinárodní komise UNESCO. Vzdělávání pro 21. století. (1997). Praha: Ústav pro informace ve vzdělávání.

Váňová, M. (1994). Vzdělávací systémy ve vyspělých evropských zemích. Praha: Karolinum.

Váňová, M. (1997). Příprava učitelů ve vybraných evropských zemích. Praha: UIV.

Vyučování a učení: cesta $k$ učící se společnosti: (Bílá kniha o vzdělávání a odborné přípravě). (1997). Praha: Učitelské noviny - Gnosis.

Walterová, E. (2006). Comparative education for teachers in the Czech Republic: Aims, models, problems. In N. Popov, C. Wolhuter, C. Keller, \& M. Kysilka (Eds.), Comparative education and teacher training (s. 41-46). Sofia: BES.

Walterová, E. (2006). Srovnávací pedagogika. Vývoj a proměny v globálním kontextu. Praha: PedF UK.

Walterová, E. (2007). Comparative education section of the Czech pedagogical society. In V. Masemann, M. Bray, \& M. Manzon (Eds.), Common interests, uncommon goals. Histories of the World council of comparative education societies and its members (s. 256-267). Hong Kong: Springer.

Walterová, E. (2008). Comparative education for teachers in the Czech republic: Aims, models, problems. In C. Wolhuter, N. Popov, M. Manzon, \& B. Leutwyler (Eds.), Comparative education at universities world wide (s. 42-46). Sofia: BES \& WCCES. Second Edition.

Walterová, E. (2014, v tisku). Proměny srovnávací pedagogiky v globální perspektivě. In D. Greger (Ed.), Srovnávací pedagogika: proměny a výzvy. Praha: PedF UK.

Wilson, M. (2005). Regression, repositioning and regeneration comparative and international education in UK higher education institutions. Příspěvek prezentovaný na UK FIET International Conference on Education and Development. Oxford (nepublikovaný manuskript referátu).

Wolhuter, C., Popov, N., Manzon, M., \& Leutwyler, B. (Eds.). (2008a). Comparative education at universities world wide. Sofia: BES \& WCCES.

Wolhuter, C., Popov, N., Manzon, M., \& Leutwyler, B. (2008b). Mosaic of comparative education at universities: Conceptual nuances, global trends and critical reflections. In C. Wolhuter, N. Popov, M. Manzon, \& B. Leutwyler (Eds.), Comparative education at universities world wide (s. 319-344). Sofia: BES.

Wolhuter, O., Popov, N., Manzon, M., \& Leutwyler, B. (2008c). List of comparative education university textbooks. In O. Wolhuter, N. Popov, M. Manzon, \& B. Leutwyler (Eds.), Comparative education at universities world wide (s. 345-360). Sofia: BES \& WCCES. 


\title{
Poděkování
}

Autorka vyslovuje dík Pavle Soustružníkové a Petře Vnukové za asistenci při organizaci a technickém zpracování výzkumu.

\section{Autorka}

Prof. PhDr. Eliška Walterová, CSc., Univerzita Karlova v Praze, Pedagogická fakulta, Ústav výzkumu a rozvoje vzdělávání, Myslíkova 7, 11000 Praha 1, e-mail: eliska.walterova@pedf.cuni.cz

\section{Problems of comparative education as a subject of teaching at universities around the world and specifically in the Czech environment}

\begin{abstract}
The study deals with comparative education as a subject of teaching at universities. It is aimed at questions not being discussed in the Czech environment. The main goal is to map the present state, and to identify problems of teaching comparative education at Czech universities, based on results of an empirical investigation performed among teachers of the subject. The first part of the study reflects trends in teaching comparative education at universities around the world, referring to international publications and projects. The second part is devoted to problems of teaching comparative education in the Czech environment. Firstly, a brief overview of specifics in the Czech environment is given. Next, results of empirical research mapping the state of teaching comparative education at Czech universities are introduced. The research process, construction of the questionnaire, and results of the research are presented. The concept, content of the subject of comparative education, and conditions of teaching are focused on. In the conclusion, the study points out potential that has not been utilized and formulates challenges for further discussion, as well as for investigation of teaching comparative education.
\end{abstract}

Keywords: comparative education, academic statute, study programmes, teachers, conception of the subject, content of the subject, potentials of the teaching comparative education. 